\title{
The foot that stalled a thousand ships: a controversial case from the 13th century BCE
}

\author{
Horton A Johnson MD
}

J R Soc Med 2003;96:507-508

The face of Helen of Troy may have launched those ships, but it was the foot of Philoctetes that delayed their return to Greece.

The ancient Greeks loved a good story, and for centuries they retold the tale of their hero Philoctetes, who held the key to victory in the Trojan War but was kept from the field of battle for ten years by a chronic disease of his foot. It was told in The Iliad, The Odyssey, The Cypria, and The Little Iliad; and the signs and symptoms described by Sophocles in his play, Philoctetes, have challenged modern-day diagnosticians.

Figure 1 shows a small oil vase, a lekythos, 5th century BCE, in the Metropolitan Museum of Art, New York. Philoctetes sits alone and downhearted, forsaken ten years earlier by his comrades, looking out over an empty sea, with his left heel bandaged. The little leafless tree seems to share his sadness. Beside him are the gifts from Heracles, his unerring bow and arrows that have allowed him to survive by shooting birds. He had been leading seven ships to Troy, but when they stopped along the way he was bitten by a water snake, resulting in a wound that would not heal, a wound so foul smelling and painful that his comrades were forced to leave their leader to die alone on the island of Lemnos.

As Sophocles' play opens, it has been prophesied that the Greeks cannot conquer Troy without the help of Philoctetes and his bow and arrows. The Greeks have dispatched Odysseus and Neoptolemus, son of Achilles, to Lemnos in the desperate hope that after ten years they might find him alive and bring him to Troy. They find his cave, his foul bandages, and then the man himself. Having been deserted by Odysseus ten years earlier he is in no mood to do them any favours, and he refuses to go with them. In the course of this conflict, Sophocles describes the symptoms.

It has been assumed that the disease described by Sophocles came from his experience rather than from his imagination. If it was a real disease known to the ancient Greeks, perhaps it can be identified today. One must, then, find the most likely diagnosis for a foot ailment initiated by a snakebite, that drained foul-smelling bloody exudates for

Three Lincoln Center \#47C, New York, NY 10023-6566, USA

E-mail: Horton_Johnson@hotmail.com

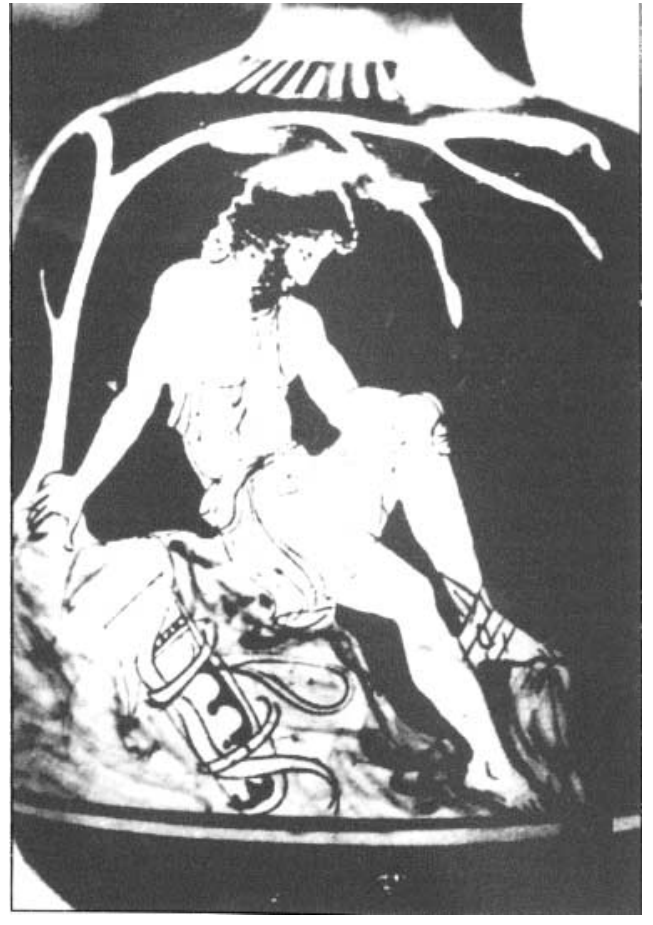

Figure 1 A lekythos in the Metropolitan Museum of Art showing Philoctetes, his left heel bandaged, abandoned by his comrades

ten years, and produced paroxysms of fever and agonizing pain. The quotations that follow are from Sophocles. ${ }^{1}$

Stefano $^{2}$ has favoured a chronically infected varicose ulcer. The excruciating pains as well as the location do not fit this diagnosis. The venous ulcer occurs on the lower leg but not on the foot, and the pain, even when the ulcer is infected, is only moderate. It does not sound like a varicose ulcer when Sophocles tells of a lesion specifically of the heel $(\alpha \kappa \rho \mathrm{o} v \pi \mathrm{o} \delta \alpha)$, nor when Odysseus says, '[His] foot was dripping from a malady that was eating it away. We could not pour libations or sacrifice in peace, but he filled the entire camp with savage and ill-omened cries, shouting and screaming' (vv. 7-11).

Urso and Fatella ${ }^{3}$ have diagnosed chromoblastomycosis. This infection, usually of the foot, is almost always found in tropical climates. Lemnos, at the same latitude as Philadelphia, has a temperate climate where 'ice was on the ground . . . in winter' (v. 293). Chromoblastomycosis is a slowly spreading fungal infection of the skin that in ten years would not have remained localized to the heel but 
would have extended beyond the foot, and very likely up to the buttocks. And even with secondary bacterial infection, the periodic, devastating pain of Philoctetes would not have been characteristic.

Grassi et al., ${ }^{4}$ impressed by the intense and episodic pain in the foot, have favoured gout. Purulent exudates from the heel would be most unusual in gout. It does not sound like gout when the chorus says, 'the burning flux oozing from the heel of his louse-ridden foot' (vv. 696-7), and when Philoctetes says, '[You are] afflicted by my cries and by my evil smell' (vv. 876-7).

Bryceson $^{5}$ thinks that Sophocles has described a mycetoma (Madura foot). Actinomycosis of the foot does produce chronic sinus tracts draining purulent exudates, but the characteristic tumefaction and deformity is not limited to the heel, and the condition is notable for its lack of pain, for which reason it has been called a 'wooden foot.' Philoctetes cries out, 'I shall not be able to conceal my pain in your company. Ah! It goes through me, it goes through me! O misery as unhappy as I am! I am lost, my son! A-a-aa-a-h! I beg you, if you have a sword handy, strike at my heel! Lop it off quickly! Do not spare my life!' (vv. 74350). That does not sound like Madura foot.

Neoptolemus assures Philoctetes that 'Meeting the sons of Asclepius, who are with us, you will be relieved of this malady' (vv. 1333-4). Bronze age physicians could have cured none of the above diseases.

Chronic osteomyelitis can account for all of these signs and symptoms. It can be initiated by a superficial wound such as the snakebite. The bacterial infection, most likely Staphylococcus aureus, spreads to form a subperiosteal abscess, occasionally of the os calcis as in this case, which destroys the blood supply to the bone. The necrotic bone, the sequestrum, acting as a foreign body, harbours a chronic infection that may drain foul sanguinopurulent exudate for many years. Periodically, when the sinus tract fails to drain, pus under pressure causes episodes of fever and intense pain, which eases when the sinus begins to drain again. Philoctetes: 'This sickness of mine returns fiercely and swiftly departs' (vv. 807-9). Neoptolemus: 'It seems that sleep will hold him before long. Yes, a sweat is pouring over his whole body, and a vein of dark blood has burst out from his heel. Come, let us leave him in peace, so that he may fall asleep' (vv. 821-7).

Chronic osteomyelitis was known to the ancient Greeks and very likely to Sophocles. It was called psiloma $(\psi \imath \lambda \omega \mu \alpha$ o $\tau \tau \varepsilon \sigma v)$, or bare bone, ${ }^{6}$ perhaps because in some cases loss of soft tissue exposed the bone, or perhaps because of the ivory white sequestrum that could at times be seen protruding from the sinus tract. Bronze age surgeons could have cured this by sequestrectomy through the sinus tract.

But back to our play. On the last page who should appear but Heracles, come down from Olympus. He bids Philoctetes go with Neoptolemus to Troy, where he will become a hero and will have his foot cured by the sons of Asclepius. Only Heracles could have convinced him. In the words of Seamus Heaney ${ }^{7}$ the chorus sings,

Go Philoctetes, with this boy, Go with him and capture Troy. Asclepius will make you whole, Relieve your body and your soul.

\section{REFERENCES}

1 Sophocles. Philoctetes. In: The Loeb Classical Library: Sophocles II (trans Lloyd-Jones M). Cambridge, MA: Harvard University Press, 1994

2 Stefano C. Philoctetes by Sophocles: a case for diagnosis. J R Coll Physicians Lond 1989;23:176

3 Urso C, Farella V. An inquiry on Philoctetes's disease. Am J Dermatol 1996;18:326

4 Grassi W, Farina A, Cervini C. The foot of Philoctetes. Lancet 1999;354:2156

5 Bryceson A. Philoctetes' foot. Lancet 2000;355:850

6 Majno G. The Healing Hand. Cambridge, MA: Harvard University Press, 1975:197

7 Heaney S. The Cure at Troy: a Version of Sophocles' Philoctetes. New York: Noonday Press, 1991 